\title{
The potency of pragmatic theoretical frameworks in the analysis of female literary writings in northern Nigeria
}

\section{Acheoah John Emike}

Ph.D., Department of European Languages, Federal University Birnin-Kebbi, Kebbi State actualemike@gmail.com

\section{Margaret Nonyerem Agu}

Ph.D., Department of English, Ibrahim Badamasi Babangida University, Lapai, Niger State, Nigeria 


\title{
The potency of pragmatic theoretical frameworks in the analysis of female literary writings in northern Nigeria
}

\author{
Acheoah John Emike*a, Margaret Nonyerem Agub \\ a Ph.D., Department of European Languages, Federal University Birnin-Kebbi, Kebbi State \\ b Ph.D., Department of English, Ibrahim Badamasi Babangida University, Lapai, Niger State, Nigeria
}

\begin{abstract}
The paper examines the potency of pragmatic theories in the analysis of female writings in northern Nigeria. As a literary genre, poetry is unique for deploying enchanting language in the communication of the poet's thematic preoccupations. In using language to communicate themes or subject matter, the poet is engaged in two basic tasks: selecting appropriate words and skillfully patterning such words with others in stretches. From classical to contemporary times, pragmatic theories are essentially theoretical frameworks for the interpretation of textual meanings - meanings which reveal language use as the performance of actions. In the analysis of Sheefah Zarma's poem ("Love"), this paper hinges on two theoretical underpinnings: Adegbija's pragmatic theory and the Pragma-crafting Theory. The significance of this study is worthy of scholarly attention; to the best of our knowledge, most studies on the pragmatic investigation of language use in literary writings focus on prose and drama because these two genres of literature are more action-revealing in terms of the dynamics of human interaction which is the core of pragmatics. It is therefore particularly significant that this study demonstrates phenomenally that even poetry can capture fascinating action-like dimensions of language use to disabuse the minds of readers who do not see poetry as speech-acts-revealing. Interestingly, this study examines the work of a young female poet from northern Nigeria, rather than that of a celebrated writer from the same region - Zeinab Alkali. This study concludes that pragmatic theories are integrative and capture the contextual underpinnings of language use.
\end{abstract}

Keywords: Pragmatic theories; Adegbija's pragmatic theory; the Pragma-crafting Theory; female literary writings; northern Nigeria.

\section{Introduction}

When language is used in literary writings, there are dimensions of meaning beyond the linguistic units that convey the sentences. This view corroborates the submission of early scholars of pragmatic theories who posit that the minimal unit of human communication is not a sentence or other expressions, but rather the performance of certain acts, such as making statements, asking questions, giving orders, describing, explaining, apologizing, etc. Indeed, this study attempts to explain language use as the performance of actions. The main objective of this study is to show that indeed, pragmatic theoretical frameworks can elucidate language use in literary writings. This paper examines the potency of pragmatic theories in the analysis of female literary works in northern Nigeria, using Sheefah Zarma's poem "Love" as a sample for analysis ${ }^{1}$. There is need for more research in the role of speech acts in the explanation of themes in literary texts; in this regard, this study fills in some gaps in the literature. Like other literary genres, poetry is used to communicate a writer's message to a wide range of audience. The messages/themes are taken from society, and to communicate to the audience, the poet is engaged in a process of constructing or meaning. In literary writings, experiences or ideas are conveyed with enchanting language to arouse readers' emotions, as noted by U. Lehtsalu, et al. (1973) who posit that "besides communicating certain ideas an

\footnotetext{
${ }^{*}$ Corresponding author

Email address: actualemike@gmail.com (Acheoah Emike)

DOI: https://doi.org/10.31559/BAES2021.6.1.2
} 
utterance may also produce a definite effect or arouse an emotion in the listener or reader. A pragmatic study of the poem "Love" is invariably an investigation of the role language plays in encoding and decoding utterances. Firth (1962) asserts that "... the meaning of an utterance is the totality of all the features in it that can be singled out ...." To convey meaning through utterances, literary writers explore aesthetic matrix. In this study, we view such aesthetic matrix as the pragmatics of writing. Fowler (1981) opines that linguistic structure is not arbitrary. It is determined and motivated by the functions it performs.

\subsection{Female Writings in Northern Nigeria}

Female writing in northern Nigeria was enhanced in the early 90s. Audee T. Giwa, (2016, p. 661) submits that "indeed the youngest female novelist to come out of Africa is from northern Nigeria. Ernest Emenyonu records her history as follows:

In 1994, Hafsa Muhammad Buba, a sixteen-year-old Muslim girl from Maiduguri, Nigeria, published an exciting 265-page novel, Peeping into Destiny, while still in secondary education at Queen's College, Lagos, making her to date the youngest female novelist of her country (p.xi)."

Unlike prose, not many works were published in poetry. For example, Audee T. Giwa (2016, p. 661) submits that “... between 1996 and 2000, about eight volumes of poetry appeared with at least several forthcoming titles. What is instructive is that the period of invisibility is now over ..."

Scholars opine that the articulation of feminist perspectives is typical of feminist literary writings. Such scholars also contend that being a northern feminist writer, may culminate into the articulation of both gender and regional concerns in literary works. Commenting on Sheefah Zarma's works, Audee T. Giwa (2016, p. 662) posits that "to understand the preoccupation of the poet in her work, one needs to note ... that Northern Nigeria is special in two ways: first, it was exposed to literacy long before the south. This literacy is Arabic in form and Islamic in content. The importance of this is premised on the fact that Arabic is perhaps the richest language where poetic expression is concerned. Sheefah Zarma is a recipient of this rich language and this is evidenced in the work ..."

\subsection{Poetry}

Poetry is a unique genre of literature in terms of language and organization. Sean 0' Brien's (2007, pp. 186187) submission is instructive:

"It is in the nature of poetry that the attempt to define a poem remains unfinished. The place to begin is by reading Aristotle's Poetics (cf. 350 BC), after which there is a vast body of description and analysis from which a number of phrases have entered common usage, including 'emotion recollected in tranquility', 'memorable speech', 'objective correlative', 'what oft was thought but ne'er so well expressed' and 'imaginary gardens with real toads in them' ... the Greek root of the word poem - poiesia - means making, an act dependent on artistry, skill, practice and let it be said - a capacity not merely for taking endless pains but for enduring perpetual dissatisfaction."

In writing a poem, the poet explores the five senses of "touch", "sound", "sight", "smell" and "taste". The depiction of phenomena will continually depend on how much a writer ensures that language used to depict or describe such phenomena is appropriate and sense-evoking.

Poetry is imaginative writing. As the poet presents his/her thematic concerns and personal emotions, he/she hinges on the principles of creative writing within the genre (poetry as verbal artistry). Language (diction) is inflated in literary writings, particularly in poetry; diction is essentially vocabulary, and it determines the quality of a literary text. The worth of a poem is accentuated by the poet's level of originality in the use of expressions. Using appropriate diction presupposes having a good grasp of the language that conveys the writer's thematic concerns; poetry is didactic, and there is no societal vice that cannot be addressed through poetry. Audee T. Giwa (2016, p. 659) submits that "the didacticism of poetry cannot be subordinated to the wanton indulgence of art for art's sake. Poetry has social relevance. It is significant in two ways: it is a sort of gateway for the release of the poet's emotions and it also touches the conscience of society ..."

\subsection{Pragmatics and Literary Writings}

Pragmatics is the study of how participants of discourse (speakers, hearers, writers, readers) use and interpret verbal and non-verbal communication. Different definitions of pragmatics abound in the literature. Such definitions have something in common: they emphasize pragmatics as context-driven use and interpretation of language. Kempson (1977) defines pragmatics as "the study of the general cognitive principles involved in the retrieval of information from an utterance." For more insights on the definition of pragmatics, see Grice (1975), Bach and Harnish (1979), Levinson (1983) and Mey (2001).

There is no limit to how participants of discourse explore the latent communicative potentials of language. Pragmatic awareness is instrumental in decoding expressions deployed by literary writers in the communication of themes. This study examines the relationship between choice of words and their meanings in the selected poem, "Love". Commenting on the production and interpretation of an utterance, Levinson (1983) submits that "understanding an utterance involves the making of inferences that are assumed or what has been said before." In decoding expressions in literary texts, the reader calculates writer-intended messages. Levinson (1983) asserts that "the interest in pragmatics developed in part as a reaction or antidote to Chomsky's treatment of language as an abstract device, or mental ability ... Generative semanticists looking for the means to undermine Chomsky's 
position, came out with philosophical thoughts devoted to the importance of the users of language to an understanding of its nature ... To this day, most of the important concepts in pragmatics are drawn directly from philosophy of language." Pragmatic analysis of language examines language use beyond its formal properties. Adegbija (1999) submits that "the scope of pragmatics includes: the message being communicated, the participants involved in the message, the knowledge of the world which they share, the deductions to be made from the text on the basis of the context and the impact of the non-verbal aspect of interaction on meaning."

In poetry, speech acts (illocutionary acts) are subtly articulated via diction. Indeed, pragmatics shows the techniques for performing illocutionary acts in literary writings. The message conveyed by an expression may not be resident in the conventional meaning of the expression. This view aligns with Savas L. Tsohatzidis $(1994$, p. 2) who submits that "... knowing what illocutionary act a speaker has performed in uttering a sentence of his language is essential for knowing what he meant in uttering that sentence; it is well known, however, that what speakers of a natural language mean by uttering sentences of that language is not always the same as what those sentences themselves mean ..." In literary writings, the pragmatics of communication shows that writer-meaning is usually intentional contents. Expressions that are deployed by poets, usually have deliberate illocutionary contents as such poets explore writer-reader thoughts and beliefs in conveying themes. Cognitive pragmatics investigates the mental states (beliefs, thoughts and intentions of speakers-hearers or writers-readers. On the whole, a pragmatic study of female literary writings in northern Nigeria is essentially an investigation of the potency of pragmatic theories in the explanation of language use in such writings.

\section{Theoretical Underpinnings}

This section of the paper briefly examines Adegbija's pragmatic theory and the Pragma-crafting Theory.

\subsection{Adegbija's Pragmatic Theory}

Adegbija (1982) was revised in Adegbija (1987). Adegbija submits that the "pragma sociolinguistic" concept (cf. 1982, p. 11) refers to the various contexts of speech which facilitate effective communication. This theory, Adegbija strongly argues, encapsulates the pragmatic, social and linguistic contexts of a given speech event. The pragma sociolinguistic concept implies the understanding of the historical, personal, environmental, sociocultural, and linguistic aspects of context relating to the context in which a particular discourse takes place. Adegbija contends that the meaning of utterances can best be explained at a super-ordinate level known as the "Master Speech Acts" level. Like Austin, Adegbija submits that when participants and circumstance are appropriate in a speech event, speech acts are felicitous. At the primary level, meanings assigned to linguistic elements contained in the utterances are decomposed in order to arrive at their meanings. Such linguistic elements include stress, intonation, pitch, rhythm and other prosodic features. No satisfactory meaning is derived at this level, although it is a means of interpreting meaning at the secondary and tertiary levels, where the pragmatic backgrounds play a very crucial role.

The secondary layer of the interpretation of an utterance yields an indirect speech act when nothing in the immediate world gives a satisfactory interpretation of the utterance at the primary level. For example, in the utterance, "She married a beast" the true relationship does not permit humans to marry beasts. Therefore, it is at a higher level of interpretation that the meaning of the utterance can be derived. Decoding such an utterance presupposes employing various types of pragmatic presuppositions: assumptions and beliefs about contexts, propositions whose truth a speaker takes for granted as part of the background of the conversation, shared beliefs or background information. At the tertiary level, presupposition helps participants of discourse to take things for granted as a result of commonly shared background knowledge. In this regard, a question can be a rebuke, a directive or an assertive based on contextual considerations. Adegbija points out that the speaker's motive for uttering an utterance is very crucial in arriving at the right interpretation of the utterance. It is also stressed, that the interpretation of utterances is also informed by the relationship between the interlocutors, the topic of the discussion and the context of the discussion. Based on the relationship between the interlocutors, a father can use "Hello" to warn his little boy, as Adegbija exemplifies. Commenting on the relevance of context in decoding utterances, Adegbija (1982, p. 159) submits that "when a well-formed, non-semantically deviant utterance appears to be irrelevant or not sufficiently relevant to the immediate context of an utterance, the relevant, non-immediate, global context of the utterance and of the speech community in which the utterance is made is readily invoked and used to infer meaning."

\subsection{The Pragma-crafting Theory}

In the Pragma-crafting Theory, Acheoah (2015) elucidates how "P-crafting Features" facilitate inferencemaking when verbal and non-verbal means of communication are deployed by the participants of discourse. Concepts in the theory include: Geoimplicatures (GIs), Linguistic Implicatures (LIs), Behavioural Implicatures (BIs), Contextual Presuppositions (CPs), Pragma deviants (PDs), Object Referred (OR) and Operative Language (OL). See Acheoah (2015) for elaborate perspectives on the theory, including the diagram. The concepts that anchor the theory are explained briefly:

- Setting: This is the physical context of the communicative event in both immediate and remote (referential) sense. 
- Theme: This is the message conveyed in/by Text.

- Sociolinguistic Variables: They are meanings conveyed by age, cultural background, social status, race, gender, relationships, etc.

- Psychological Acts: These are the different emotions expressed through linguistic and extra-linguistic acts.

- Inference: Inference-making has to do with making logical deductions from available linguistic and extralinguistic components of Text.

- Indexicals: They are grammatical categories that have the potential to establish the relationship between language and context.

- Shared Contextual Knowledge: This refers to available pieces of information available to participants of the on-going discourse for effective communication.

- Emergent Context: It is any emergent situation in an on-going communicative event. It redirects the performance and interpretation of subsequent linguistic, extra-linguistic and psychological acts. An emergent context becomes Shared Knowledge of Emergent Context when it translates into common knowledge of the participants of discourse.

- Geoimplicature: Coined from "geographical" and "implicature", the term "Geoimplicature" refers to verbal and non-verbal practices that are restricted to race and geographical (physical) boundary; they are not universal human behaviour.

- Linguistic Implicature: It is any meaning implied through language.

- Behavioural Implicature: It is any meaning conveyed by extra-linguistic and psychological acts.

- Contextual Presupposition: This is a product of shared contextual knowledge.

- Background Assumptions: In an on-going communication, participants deduce meanings from verbal and non-verbal data. Such meanings are referred to as Background Assumptions (BAs).

- Pragma deviants: They are deviant expressions used by participants of discourse, as illocutionary strategies.

- Interactive Participant: This is an interlocutory participant who performs linguistic, extra-linguistic and psychological acts, as communicative contributions that do not only impinge on the interpretive process, but also determine or generate sequel (perlocutionary act).

- Non-interactive Participant: A non-interactive participant does not participate in an on-going communicative event but is intentionally or accidentally present in the physical context.

\section{Methodology}

We do not know of any literary work that is strictly northern in terms of plot, style and theme. Therefore the choice of Sheefah Zarma's poem is simply informed by the fact that she is an evolving literary writer from that region of Nigeria. The less attention given to poetry in the analysis of speech acts in literary texts, is also a reason for the choice of the poem, "Love" in this study. The analysis hinges on the Content Analysis Method (cf. Babbie (1986). According to Babbie (1986, cited in Asika 1991), the Content Analysis Method is the most appropriate in analyzing any form of communication. Used frequently in the study of such artifacts as books, magazines, poems, newspaper features, songs, paintings, letters, laws and other printed matters, the Content Analysis Method is suitable for the study of communication and for answering the classic communication research questions: Who says what, to whom, why, how, and with what effect?. Linguistic research requires that we define the units of analysis, i.e. the individual units about which or from which descriptive and explanatory comments are to be made. In this study, the units of analysis are the analyzed theme-driven expressions.

Besides the two major theoretical frameworks explored in this study, we rely on Bach and Harnish's speech act taxonomy in the presentation of speech act sequencing in the poem, "Love". This is done in tabular form, indicating the frequencies and percentages of the deployed speech act categories (simple statistics).

\section{Towards a Pragmatic Approach to the Study of Female Literary Writings in Northern Nigeria}

A pragmatic approach to the study of female literary writings in northern Nigeria shows the link between one contextual feature of the inferential process and another. This is a major strength of Adegbija's pragmatic theory as it captures the relationship between "macro-context" (broad/remote context) and micro-context (immediate context) in the inferential process. In Adegbija's theory, the social context is about the relationships that bind the participants in any interaction. In the poem "Love", the social context reveals human-animal-plant relationship; the predications in lines 15 and 17 concern animal (bee), plant (flower) and humans (the wealthiest):

\section{I am the flower to the bee (line 15)}

Yet even the wealthiest need me (17)

The poet's message is clear: the quest for love inevitably unifies these entities. Love is precious, love is universal. Love is invaluable and all creatures desire it. It is interesting that the poet makes the readers understand that it is not only humans that desire or show love. The poet's analogical use of "flower" and "bee" is an attempt to describe a situation that is different from the human practice of love; the analogy is simply about the strong irresistible charming influence that love has on its "victim(s)". The poem addresses humans (immediate/micro context) by invoking a broad/remote/macro context. Interestingly, the poet is aware that the literary/pragmatic 
device can be processed by the reader for optimal relevance. According to Sperber and Wilson's (1986) theory of relevance, "relevant information is that which yields the greatest change in the hearer's knowledge for the least processing efforts." Language use directed towards an addressee (reader/hearer) is usually an intentional act and a speech act, whether it is spoken or written. Considering the fact that female literary writings in northern Nigeria are immersed in the communication of intentions/messages/thematic concerns, pragmatic theories can be explored in the analysis of such writings. John T. Kearns, cited in Savas L. T. (1994, p. 50) posits that "a linguistic act, or speech act, is an intentional, meaningful act performed with an expression or expressions. Even though the word 'speech' suggests saying something out loud, I use the two expressions 'speech act' and 'linguistic act' interchangeably for acts performed with expressions, whether they are out loud, in writing, or 'in one's head'. Both speakers/writers and their audiences (when they understand the speakers/writers) perform linguistic acts." Given the style with which the poet addressed the subject (love), the audience are made to participate in the poet's message; like the poet, the readers are people who practice, experience or desire love.

This study regards the poem "Love" as writer-reader interaction. Therefore, the language therein performs social actions. The poet ascribes different meanings to love, and attempts to convey such meanings to the readers. David A. Brenders (1987, p. 329) posits that "one of the central issues involved in any systematic analysis of communication is the role of "meaning" in conversation. One general trend in such analyses has been to regard meaning as the products of social action. While this approach promotes the sensible idea that communication is the product of social actors in context rather than the mere adherence to language rules, this position has tended to blur the distinction between semantic and pragmatic meaning, and illocutionary versus perlocutionary acts. As a result, slogans such as “Words don't mean, people mean," are used widely, while research proceeds with little or no discussion of whether this approach yields consistent and sensible analyses of meaning in communication."

Sheefah Zarma rightly notes that love is not restricted to class - and by extension, it is neither restricted to race nor region:

Yet even the wealthiest need me (17)

Sheefah Zarma explores readers' background knowledge (presupposition); he explores readers' awareness, admiration, experience, natural instinct concerning "love". In the Pragma-crafting Theory, presuppositions and shared knowledge operate as Background Assumptions (BAs). Hinging heavily on the concept of presupposition, pragmatic theories are potent frameworks for textual analysis. Different perspectives are in the literature on the concept of presupposition. These perspectives direct the interpretation of the poem "Love" in this study. One of such perspectives is that of Caffi, (cited in Mey 2001, p. 186) who opines that "pragmatic presuppositions not only concern knowledge, whether true or false: they concern expectations, desires, interests, claims, attitudes towards the world ..." Marmaridou (2000) also makes an instructive submission on presupposition: "Pragmatic approaches towards presupposition have mainly drawn upon the theory of speech acts and that of conversational implicatures."

Adegbija's theory explains that participants' background knowledge (mutual contextual beliefs) does not only facilitate the use of verbal and non-verbal means of communication, but also enhances the interpretation of messages in varied contexts. In the poem "Love", Sheefah Zamar presupposes that the readers are already aware that nobody can control the powerful effect of love when it invades and controls the human mind. The readers who are familiar with William Shakespeare's Romeo and Juliet will align with Sheefah Zamar's message. The reader is subjected to working out the topic relevance of "weird heartthrobs" (line 2) from individualistic experiences.

In Adegbija's theoretical framework, the "pragma sociolinguistic" concept also captures the interpretation of indirect speech acts. An indirect speech act is an utterance "in which one says one thing and means another, or says one thing and means what one says and also means another illocution with a different propositional content" Adegbija (1982, p. 34). Adegbija believes that background knowledge facilitate the working out of the meanings of indirect speech acts. A pragmatic approach to the study of female writings in northern Nigeria helps the analyst to determine indirect speech acts and implicatures. According to Laurence (2006), "implicature is a component of speaker meaning that constitutes an aspect of what is meant in a speaker's utterance without being part of what is said."

Adegbija explains that the linguistic context has to do with the choice of words in stretches in terms of words before and after a particular word in such stretches. The poet's choice of words effectively conveys pungent, clear message about love: love is blind. Consider lines 9 and 10:

\section{Creeping into your soul (line 9)}

Placing a veil so you cannot see (line 10)

From our knowledge of the conventional meaning of "sweet" and "bitter" (conventional implicature), we can infer the poet's additional messages about love: love is elusive, transient, pleasant and painful. The use of the expression "soul" portrays love as a spiritual phenomenon. The body dies, the soul does not; love is eternal:

Your soul craves for it ... (line 3 )

The poet's selection of words are intentionally theme-driven. According to John T. Kearns (cited in Savas L. T. 1994, p. 51), "the words used to perform linguistic acts are not meaningful. But words are conventionally associated with certain types of acts and will normally be used to perform these kinds of acts. The meaning of someone's linguistic act is her intention for the act. Most words are conventionally associated with more than one type of act. The language user's intention determines which particular type of act she performs. And it is common, by a slip of the tongue or carelessness, for a speaker to use the wrong word in performing a linguistic act. She still performs the 
kind of act she intends, but the expression she uses will probably mislead her audience."

Communication cannot be realized without participants. This point is emphasized in Adegbija's pragmatic theory. The pragmasociolinguistic concept captures participant-related elements of communication; Adegbija contends that personal, environmental and socio-cultural factors determine effective communication. In the poem "Love", the personal pronouns "you", "your" and "I" (in lines 3, 4, 5, 6 and 7) show that poetry explores participantelement in the communication of themes. These personal pronouns are used by the poet for pragmatic reference and predication (proposition). Speech acts are conveyed by propositions by attaching the subject/message to the addressees (participatory device). Consider the literary effects of the pronouns "your" and "you" in the following lines of the poem:

\author{
Your soul craves for it (line 3) \\ You do not understand the situation (line 4) \\ It smiles at you. (line 5) \\ It makes you cry (line 6) \\ Why don't you understand? (line 7)
}

Even if a poem does not feature participants who are engaged in interior dialogue, the poet communicates to the readers who are in the position of participants in the poetic interaction. In this regard, the participants can be regarded as fictional characters. In the poem "Love", if we view the encoder of "Listen ..." (line 1) as the poet, this poet presupposes that the readers represent the human qualities of several people; that is, Sheefah Zamar presupposes that just like she does, other human beings generally desire love and enjoy being loved. In other literary genres, to make fictional characters ring true and fascinating, the writer explores his/her own desires, expectations and character traits in conveying themes.

Adegbija contends that a speech act approach to the study of Nigerian literature is very rewarding. He notes that through indirect speech acts, writers can effectively communicate difficult messages. His Master Speech Act notion helps show: theme-driven speech act sequencing in literary works; contextual structures that produce the Master Speech Act in a body of discourse such as female literary writings in northern Nigeria; the relationship between the Master Speech Act and other illocutionary acts across an entire literary text. Usually, the Master Speech Act is a clear, thought-provoking statement. In Sheefah Zamar's poem "Love", the speech act sequencing is fascinating:

\author{
Listen to the sound so deep (Requestive/Ascriptive) \\ The weird heartthrobs (Ascriptive) \\ Your soul craves for it (Declaration) \\ You do not understand the situation (Declaration) \\ It smiles at you. (Declaration) \\ It makes you cry (Ascriptive) \\ Why don't you understand? (Question) \\ It comes. \\ Creeping into your soul \\ Placing a veil so you cannot see (Ascriptive/Informative/Declaration) \\ Making you handicap (Informative/Declaration) \\ Listen \\ It says once more (Informative/Requestive) \\ I am the sweet bitter fantasy (Ascriptive/Informative/Declaration) \\ I am the flower to the bee (Ascriptive/Informative/Declaration) \\ I am not bought (Ascriptive/Informative/Declaration) \\ Yet even the wealthiest need me (Informative/Ascriptive) \\ I am what you have been waiting for (Ascriptive/Informative/Declaration) \\ Succor I am to your long tearful nights \\ (Ascriptive/Informative/Declaration) \\ Here I am to be part of you. (Commissive)
}

The poem "Love" reveals six discrete speech act categories: Requestives, Ascriptives, Declarations, Question Commissive and Informatives.

Table (1): below shows the frequency and percentage

\begin{tabular}{lcc}
\hline \multicolumn{1}{c}{ Speech Act } & Frequency & Percentage \\
\hline Requestives & 2 & $6.0 \%$ \\
Ascriptives & 10 & $30.3 \%$ \\
Declarations & 10 & $30.3 \%$ \\
Question & 1 & $3.0 \%$ \\
Commissive & 1 & $3.0 \%$ \\
Informatives & 9 & $27.2 \%$ \\
\hline
\end{tabular}




\section{Table 1: Speech Act Sequencing in the Poem "Love"}

The Master Speech Acts in the poem are Ascriptives (30.3\%) and Declarations (30.3\%). Having a two-fold Master Speech Act is not incidental; the literature of pragmatics acknowledges that the classification of speech act is intractable because speech acts are versatile. There are contexts in which using one speech act implies using

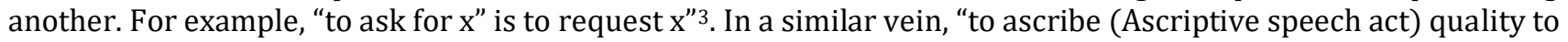
the theme of the poem (love) is "to declare (Declarative speech act) that love has such qualities". The Ascriptives are used to make declarations about the subject "love". The poet uses speech act sequencing to arrest the readers' attention and arouse their emotion. In the Pragma-crafting Theory, "Psychological Acts" are the feelings or emotions which expressions or utterances produce in the minds of hearers or readers.

It is logical to posit that the contextual structures used by the poet to convey the themes include:

- "forest" (I am the flower to the bee - line 15);

- "market" (I am not bought-line 16);

- "home" /" domestic" setting (Succor I am to your long tearful nights - line 19).

In the Pragma-crafting Theory, "Setting" is equivalent to "contextual structure", a term used by Adegbija. The use of the expressions "flower" and "bee" to invoke the contextual structure (forest) in the poem, corroborates Acheoah's (2015) submission that besides being the physical context of a communication event, setting is also the referential sense of location that an expression or utterance invokes.

Scholars hold the view that utterances have external relations; decoding Sheefah Zarmah's message in the poem, presupposes invoking extra-linguistic elements of the situational context such as the real world where the readers practice or experience love and the representations given to it by the writer. This view aligns with that of Bennett (1998) who submits that "language does serve as a tool for communication, but in addition, it is a 'system of representation' for perception and thinking." Use of language in poetry is theme-dependent, rather than being arbitrary. For effective literary writings, northern female writers explore the mental states they share with their immediate and remote audience.

\section{Summary}

Pragmatic theories are evolved by language philosophers. These philosophers acknowledge that the goals of pragmatics is to process language for smooth communication. In addressing themes such as love, peace or rebellion, a poet explores implicatures, expecting readers to interpret such themes individually. Scholars hold the view that implicature essentially involves mind-reading, and there is no limit to inference-making from writers' expressions or speakers' utterances. In northern female literary writings, messages are conveyed with creative ingenuity and individualistic inclinations. Perhaps, this is why poetry is often viewed as an ideal genre for creative writing tasks. From classical to contemporary times, poetry has been used to convey multifaceted themes: love, hate, hope, fraternity, climate change, corruption, etc. Language use in poetry is essentially a reflection of writer-reader interaction. In Sheefah Zarmah's poem "Love", decoding language use involves the making of inferences. This study shows that readers of literary texts have to reasonably establish the rationale for working out the meanings of expressions used in such texts. Literary writers try to make their messages easy to process. This they do, by assuming that their psychological state is same as that of their audience/readers. This device facilitates inferencemaking. Adegbija (1982) posits that "inference involves the drawing of a conclusion from known or assumed facts or statements, from available data or a particular premise. It is the deductive process through which the addressee or reader progresses from the literal meaning of an utterance to what the speaker/writer actually intends to express. The context of an utterance is often very crucial in making the appropriate inference. Inferences are made on the basis of the background context, our experience of life or world knowledge, and the mutually shared beliefs. Knowledge of the literal meaning of an utterance often contributes to appropriate inference that will lead us to the non-literal meaning." Commenting further on inference, Ariel, cited in Rita Bossan (2018) notes that "pragmatics is responsible for inferences which are based on the linguistic strings expressed when contextual assumptions are taken into account." This view aligns with that of Brumfit and Johnson (1979) who submit that "the ability to compose sentences is not the ability we need to communicate. Communication only takes place when we make use of sentences to perform a variety of different acts of an essentially social nature. Thus we do not communicate by composing sentences, but by using sentences to make statements of different kinds, to desire, to record, to classify, and so on, or to ask questions, make requests, give orders, etc. Knowing what is involved in putting sentences together correctly is only one part of what we mean by knowing a language, and it has very little value on its own. It has to be supplemented by knowledge of what sentences contain as in their normal use as a means of communication."

\section{Conclusion}

A pragmatic study of the poem "Love" shows that the poet is involved in exploring her understanding of the human mind as it relates to various phenomena. The production and interpretation of utterances are essentially motivated by principles, and these principles operate as pragmatic features of the given communication event. The implication of this study is that it advances knowledge in the explanation of how speech act categories and frequency impinge on the overall message in a literary text. 


\section{Notes:}

1. See the appendix section for the poem.

2. The speech act categories above are taken from Bach and Harnish's (1979) speech act taxonomy.

3. ... where $\mathrm{x}$ is an infinite referent.

\section{References}

1. Acheoah, J. E. (2015). The Pragma-crafting theory: A proposed theoretical framework for pragmatic analysis. American Research Journal of English and Literature, 1(2): 21-32, https://doi.org/10.21694/2378-9026.15019.

2. Adegbija, E. F. (1982). A speech act analysis of consumer advertisements, Bloomington: Indiana University. Ph.D. Dissertation.

3. Adegbija, E. F. (1987). Speech act function: Dimension of communication and meaning in the English language in Nigeria. ITL Review of Applied Linguistics, (76): 43-67, https://doi.org/10.1075/itl.76.03ade.

4. Adegbija, E. F. (1999). The English language and literature in English: An introductory handbook, Ilorin: University of Ilorin.

5. Asika, N. (1991). Research methodology in behavioural sciences. Ikeja: Longman.

6. Audee, T. G. (2016). Strategic essentialism and the female voice in northern Nigeria: Sheefah Zarma's poetry in postcolonial perspective. In Ayodabo et al. (eds.), Linguistics, language, and literature: A festschrift for Gbenga Solomon Ibileye, Lokoja: Department of English and Literary Studies, Federal University, Lokoja, Kogi State.

7. Bach, K. \& Harnish, R. (1979). Linguistic communication and speech acts, Cambridge, Massachusetts. The MIT Press.

8. Bennett, D. (1989). Multicultural stages: Rethinking difference and identity. London: Routledge.

9. Bossan, R. (2018). History and scope of pragmatics. In O. Ibileye (ed.), Discourse analysis and pragmatics: Issues in theory and practice, Lagos: Malthouse Press Limited.

10. Brumfit, C. J. \& Johnson, K. (1979). The communicative approach to language teaching, Oxford: Oxford University Press.

11. Brenders, D. A. (1982). Fallacies in the coordinated management of meaning: A philosophy of language critique of the Hierarchical Organization of Coherent Conversation and Related Theory. Quarterly Journal of Speech, 73(3): 329-348, https://doi.org/10.1080/00335638709383812.

12. Firth, J. R. (1962). A Synopsis of linguistic theory. In Studies in linguistic analysis. London: Philosophical Society.

13. Grice, H. (1975). Logic and conversation. In Cole and Morgan (eds.).

14. Kempson, R. (1977). Semantic theory, New York: Cambridge University Press.

15. Laurence, R. H., Implicature, In Laurence, R. H. \& W. Gregory (2006). The Handbook on pragmatics. USA: Blackwell Publishing.

16. Levinson, S., (1983). Pragmatics, Cambridge: Cambridge University Press.

17. Lehtsalu, U., Liiv, G. \& Mutt, O. (1973). An introduction to English stylistics. Tartu: Tartu State University.

18. Mamaridou, S. S. A. (2000). Pragmatic meaning and cognition, Amsterdam \& Philadelphia: John Benjamins Publishing Company.

19. Mey, J. (2001). An introduction to pragmatics. Oxford: Blackwell Publishing.

20. Savas, L. T. (1994). Foundations of speech act theory. London: Routledge.

21. Sean, O' B. (2007). Introduction to poetry, In Steven Earnshaw (ed.), The handbook of creative writing. Edingburgh: Edingburgh University Press.

22. Sperber, D. \& Wilson, D. (1986). Relevance, communication, and cognition. United Kingdom, Blackwell Publishing. 


\section{Appendix}

LOVE

Listen to the sound so deep

The weird heartthrobs

Your soul craves for it

You do not understand the situation

It smiles at you.

It makes you cry

Why don't you understand?

It comes.

Creeping into your soul

Placing a veil so you cannot see

Making you handicap

Listen

It says once more

I am the sweet bitter fantasy

I am the flower to the bee

I am not bought

Yet even the wealthiest need me

I am what you have been waiting for

Succor I am to your long tearful nights

Here I am to be part of you. 